\title{
Oestrogens and progestagens in rat ovarian follicles during the oestrous cycle
}

\author{
Maria Szoltys \\ Department of Animal Physiology, Jagiellonian University, Cracow, Poland
}

\begin{abstract}
Summary. The amounts of follicular oestrogens increased simultaneously with the growth of follicles to reach a maximum on the day of pro-oestrus at 18:00 h, then decreased rapidly. Progestagens were detectable only in large follicles excised at pro-oestrus. Small follicles at pro-oestrus contained small amounts of oestrogens.
\end{abstract}

\section{Introduction}

Concentrations of steroid hormones in blood plasma during the oestrous cycle of the rat have been reported by many investigators (Hori, Ide \& Miyake, 1968; Schwartz, 1969; Brown-Grant, Exley \& Naftolin, 1970; De Paolo, Shander, Wise, Barraclough \& Channing, 1979). There are, however, no data concerning steroid levels correlated with the stage of the oestrous cycle in the various compartments of the ovary. This problem seemed to be of interest, and as the first compartment investigated, ovarian follicles were chosen. This choice was influenced by our finding that the granulosa cells were responsible for preovulatory progestagen synthesis in large pro-oestrous follicles (Noworyta \& Szoltys, 1975).

\section{Materials and Methods}

A total of 65 female Wistar rats was used; the animals were kept on a $12 \mathrm{~h}$ light/12 $\mathrm{h}$ dark schedule (light from 08:00 to 20:00 h) and fed an ordinary laboratory diet ad libitum. Oestrous cycles were followed by the condition of vaginal smears and only females showing at least 3 consecutive 4-day cycles were included. Rats were killed by cervical dislocation at 11:00 and 18:00 $\mathrm{h}$ on the days of oestrus, metoestrus and dioestrus and at 08:00, 11:00 and 14:00 $\mathrm{h}$ on the day of pro-oestrus and then every $2 \mathrm{~h}$ until $02: 00 \mathrm{~h}$ the next day, i.e. before ovulation, which took place between 02:00 and 04:00 h.

Ovaries were excised and, under the dissecting microscope, the largest follicles were dissected out and very carefully cleaned from adjacent interstitial tissue; on the day of pro-oestrus at 11:00 h, small follicles were also obtained. The diameter of follicles was measured by means of a micrometer scale mounted into the dissecting microscope, then they were weighed, frozen and stored at $-20^{\circ} \mathrm{C}$. For steroid analysis, follicles isolated from ovaries of a single rat (usually $5-8$ ) were homogenized in $1 \mathrm{ml}$ phosphate buffer $(0.14 \mathrm{M}-\mathrm{NaCl}, 0.01$

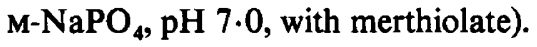

Oestrogens were estimated by a radioimmunoassay (Hotchkiss, Atkinson \& Knobil, 1971) using $\left[2,4,6,7-{ }^{3} \mathrm{H}\right]$ oestradiol (sp. act. $105 \mathrm{Ci} / \mathrm{mmol}$ : New England Nuclear, Frankfurt, Germany) as tracer and an antibody raised in sheep against oestradiol-17 $\beta$-succinyl-bovine serum albumin (a gift from Dr B. V. Caldwell). The lower limit of sensitivity of the assays was of 
the order of $5 \mathrm{pg}$. Cross-reactions for 13 steroids were below $1 \%$, but oestrone showed $40 \%$ and oestriol $6 \%$ cross-reaction. Coefficients of variation within and between assays were below $7.5 \%$ and $8 \%$ respectively. Progestagens were measured by radioimmunoassay (Abraham, Swerdloff, Tulchinsky \& Odell, 1971) using $\left[1,2,6,7-{ }^{3} \mathrm{H}\right]$ progesterone (sp. act. $81 \mathrm{Ci} / \mathrm{mmol}$ : The Radiochemical Centre, Amersham) as a tracer and an antibody produced in sheep immunized against 11 $\alpha$-hydroxyprogesterone succinyl-bovine serum albumin (a gift from $\mathrm{Dr}$ B. Cook). Sensitivity of assays was $50 \mathrm{pg}$ and the limits of assays were $2000 \mathrm{pg}$. Cross-reaction was $5 \%$ with pregnenolone, $1.8 \%$ with $20 \alpha$-hydroxy-pregn-4-en-3-one, $1.9 \%$ with oestradiol- $17 \beta$ and $1.1 \%$ with $17 \beta$-hydroxyprogesterone. Binding of other steroids was below $1 \%$. Coefficients of variation within and between assays were below $7.5 \%$ and $8 \%$ respectively. For oestradiol, assay aliquots of 50-100 $\mu \mathrm{l}$ of homogenates were extracted with ethyl ether, and for progesterone assay aliquots of $100-200 \mu \mathrm{l}$ of homogenates were extracted with hexane. All samples were assayed in duplicate. All reagents were of analytical grade and distilled before use. Tracers were checked every 3 months and, if necessary, purified by column chromatography using Sephadex LH-20. The amount of hormone was calculated as per mg of follicular tissue and per follicle.

\section{Results}

Follicular diameters and weights are given in Table 1. The oestrogen values reached a peak at 18:00 $\mathrm{h}$ on the day of pro-oestrus and then dropped sharply (Text-fig. 1; Table 1). Progestagens were only measurable from late on the day of pro-oestrus.

Table 1. Oestrogens in rat follicles during the 4-day oestrous cycle

\begin{tabular}{|c|c|c|c|c|c|c|}
\hline \multirow[b]{2}{*}{$\begin{array}{l}\text { Stage of } \\
\text { cycle }\end{array}$} & \multirow[b]{2}{*}{$\begin{array}{l}\text { No. of } \\
\text { animals }\end{array}$} & \multirow[b]{2}{*}{$\begin{array}{l}\text { No. of } \\
\text { isolated } \\
\text { follicles }\end{array}$} & \multirow[b]{2}{*}{$\begin{array}{l}\text { Follicle diam. } \\
\qquad(\mu \mathrm{m})\end{array}$} & \multirow[b]{2}{*}{$\begin{array}{l}\text { Follicle wt } \\
\text { (mg) }\end{array}$} & \multicolumn{2}{|c|}{ Oestrogen } \\
\hline & & & & & $\begin{array}{c}\mathrm{pg} / \mathrm{mg} \\
\text { follicular } \\
\text { tissue }\end{array}$ & $\mathrm{pg} /$ follicle \\
\hline \multicolumn{7}{|l|}{ Oestrus } \\
\hline $\begin{array}{l}11: 00 \mathrm{~h} \\
18: 00 \mathrm{~h}\end{array}$ & $\begin{array}{l}4 \\
4\end{array}$ & $\begin{array}{l}21 \\
23\end{array}$ & $\begin{array}{l}650.0 \pm 20.5 \\
677.0 \pm 53.0\end{array}$ & $\begin{array}{l}0.25 \pm 0.02 \\
0.29 \pm 0.02\end{array}$ & $\begin{array}{l}45.3 \pm 10.6 \\
31.3 \pm 10.5\end{array}$ & $\begin{array}{r}12.5 \pm 2.3 \\
8.1 \pm 2.6\end{array}$ \\
\hline \multicolumn{7}{|l|}{ Metoestrus } \\
\hline $\begin{array}{l}11: 00 \mathrm{~h} \\
18: 00 \mathrm{~h}\end{array}$ & $\begin{array}{l}4 \\
4\end{array}$ & $\begin{array}{l}31 \\
23\end{array}$ & $\begin{array}{l}701.8 \pm 10.2 \\
732.7 \pm 3.2\end{array}$ & $\begin{array}{l}0.30 \pm 0.05 \\
0.30 \pm 0.03\end{array}$ & $\begin{array}{l}54.6 \pm 11.4 \\
85.0 \pm 22.6\end{array}$ & $\begin{array}{l}15.6 \pm 3.0 \\
29.3 \pm 7.0\end{array}$ \\
\hline \multicolumn{7}{|l|}{ Dioestrus } \\
\hline $\begin{array}{l}11: 00 \mathrm{~h} \\
18: 00 \mathrm{~h}\end{array}$ & $\begin{array}{l}4 \\
5\end{array}$ & $\begin{array}{l}31 \\
31\end{array}$ & $\begin{array}{l}780.0 \pm 1.1 \\
813.7 \pm 10.4\end{array}$ & $\begin{array}{l}0.36 \pm 0.01 \\
0.44 \pm 0.06\end{array}$ & $\begin{array}{l}167.0 \pm 32.9 \\
329.4 \pm 53 \cdot 1\end{array}$ & $\begin{array}{r}78.0 \pm 6.6 \\
138.1 \pm 23.3\end{array}$ \\
\hline \multicolumn{7}{|l|}{$\begin{array}{l}\text { Pro-oestrus } \\
\text { Small } \\
\text { follicles }\end{array}$} \\
\hline $\begin{array}{l}11: 00 \mathrm{~h} \\
\text { Preovulatory } \\
\text { follicles }\end{array}$ & 4 & 34 & $539.5 \pm 10.6$ & $0.29 \pm 0.01$ & $14.0 \pm 2.4$ & $5.9 \pm 1.6$ \\
\hline $08: 00 \mathrm{~h}$ & 4 & 26 & $929.1 \pm 16.7$ & $0.48 \pm 0.02$ & $595.8 \pm 68.8$ & $274.3 \pm 14 \cdot 7$ \\
\hline $11: 00 \mathrm{~h}$ & 4 & 23 & $933.9 \pm 17.7$ & $0.53 \pm 0.04$ & $467.7 \pm 39.0$ & $245.8 \pm 15 \cdot 1$ \\
\hline $14: 00 \mathrm{~h}$ & 4 & 34 & $875.9 \pm 22.3$ & $0.51 \pm 0.03$ & $720.9 \pm 45.4$ & $372.6 \pm 36.3$ \\
\hline $16: 00 \mathrm{~h}$ & 4 & 33 & $981.2 \pm 6.7$ & $0.55 \pm 0.05$ & $657.3 \pm 72.8$ & $363.0 \pm 31.8$ \\
\hline $18: 00 \mathrm{~h}$ & 4 & 21 & $1044.9 \pm 81.2$ & $0.52 \pm 0.01$ & $850.2 \pm 34.6$ & $440.8 \pm 16.4$ \\
\hline $20: 00 \mathrm{~h}$ & 4 & 23 & $1065.3 \pm 23.4$ & $0.52 \pm 0.03$ & $498.9 \pm 34.7$ & $253.8 \pm 6.2$ \\
\hline $22: 00 \mathrm{~h}$ & 4 & 24 & $1093.9 \pm 6.0$ & $0.56 \pm 0.02$ & $53.7 \pm 8.1$ & $29.8 \pm 6.0$ \\
\hline $24: 00 \mathrm{~h}$ & 4 & 30 & $1164.9 \pm 23.1$ & $0.68 \pm 0.04$ & $37.0 \pm 6.7$ & $24.2 \pm 3.8$ \\
\hline $02: 00 \mathrm{~h}$ & 4 & 19 & $1218.2 \pm 5.0$ & $0.88+0.12$ & $21.6 \pm 4.3$ & $15.9 \pm 2.7$ \\
\hline
\end{tabular}

Values are mean \pm s.e.m. 


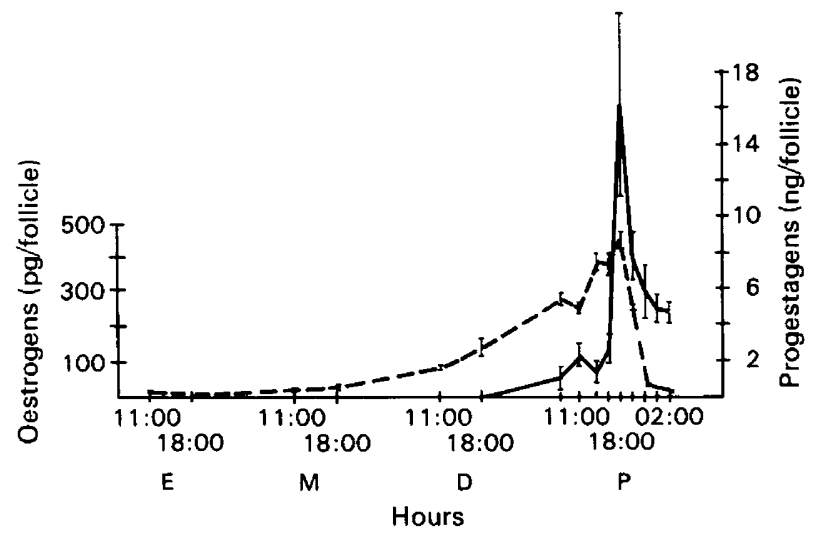

Text-fig. 1. Oestrogens and progestagens in rat follicles during the 4-day oestrous cycle. $(E=$ oestrus; $M=$ metoestrus; $D=$ dioestrus; $P=$ pro-oestrus). Values are mean \pm s.e.m. for the no. of rats indicated in Table 1.

\section{Discussion}

Plasma oestrogen concentrations are low during oestrus and metoestrus, and increase in dioestrus to reach a maximum in the morning or early afternoon of pro-oestrus. Brown-Grant $e t$ al. (1970) observed an oestrogen decrease by noon, Smith, Freeman \& Neill (1975) at 15:00 h and De Paolo et al. (1979) after 16:00 h on the day of pro-oestrus, while Hori et al. (1968) and Shaikh (1971) reported a decrease after 18:00 h and only trace amounts by 22:00 h.

The present results correlate well with this pattern. As in plasma, follicular oestrogens were low in oestrus and metoestrus and then increased in dioestrus. Only in pro-oestrus did maximum levels in plasma precede maximum levels within follicles. At 12:00 h on the day of pro-oestrus, however, large follicles contained large amounts of oestrogen which could have been released into the circulation because such follicles placed in culture released $>5 \mathrm{pg}$ oestrogens per follicle during $24 \mathrm{~h}$ culture (unpublished data). The follicles might also take up oestradiol preferentially like those of mares (YoungLai \& Short, 1970). During the evening and night before oestrus and ovulation, oestrogen levels in plasma and follicles were very low.

Progestagen levels in plasma during the oestrous cycle show 2 peaks, a lower one in metoestrus or dioestrus and a higher one in pro-oestrus (Hashimoto, Henricks, Anderson \& Melampy, 1968; McDonald, Seiki, Prizant \& Godolfien, 1969; Barraclough, Collu, Massa \& Martini, 1971; Piascek, Schneider \& Gay, 1971; Smith et al., 1975; De Paolo et al., 1979). The latter is of follicular origin (Szoltys, 1976). Since follicles do not release progestagens in metoestrus and dioestrus, the source of the former progestagen increase is possibly corpora lutea or interstitial tissue. To prove this, however, investigations of steroid levels in other ovarian compartments are necessary.

This investigation was supported by NIH PL 480 Research Agreement No. 05-001-0 Annex 05-040-N. I am grateful to Dr S. Stoklosowa for suggesting the problem and critical remarks during this study, to Dr B. Cook for his advice in preparation of the manuscript, and to WHO for SSP support.

\section{References}

Abraham, G.E., Swerdloff, R., Tulchinsky, D. \& Odell, W.D. (1971) Radioimmunoassay of plasma progesterone. J. clin. Endocr. Metab. 32, 619-624.
Barraciough, C.A., Collu, R., Massa, R. \& Martini, L. (1971) Temporal interrelationship between plasma LH, ovarian secretion rates and peripheral plasma 
progestin concentration in the rat. Effects of Nembutal and exogenous gonadotrophins. Endocrinology 88, 1437-1447.

Brown-Grant, K., Exley, D. \& Naftolin, F. (1970) Peripheral plasma oestradiol and luteinizing hormone concentrations during the oestrous cycle of the rat. J. Endocr. 48, 295-296.

De Paolo, L.V., Shander, D., Wise, P.M., Barractough, C.A. \& Channing, C.P. (1979) Identification of inhibin-like activity in ovarian venous plasma of rats during the estrous cycle. Endocrinology 105, 647654.

Hashimoto, I., Henricks, D.M., Anderson, L.L. \& Melampy, R. (1968) Progesterone and pregn-4en-20-ol-3-one in ovarian venous blood during various reproductive states in the rat. Endocrinology 82, 143-148.

Hori, T., Ide, M. \& Miyake, T. (1968) Ovarian oestrogen secretion during the oestrous cycle and under the influence of exogenous gonadotrophins in rats. Endocr. Jap. 15, 215-222.

Hotchkiss, J., Atkinson, L.E. \& Knobil, E. (1971) Time course of serum estrogen and luteinizing hormone (LH) concentration during menstrual cycle of the rhesus monkey. Endocrinology 89, 177-183.

McDonald, D.M., Seikl, K., Prizant, M. \& Godolfien, A. (1969) Ovarian secretion of progesterone in relation to the Golgi apparatus in lutein cells during estrus of the rat. Endocrinology 85, 236-243.
Noworyta, B. \& Szoltys, M. (1975) Dynamics of the $\Delta^{5}$-3 $\beta$-hydroxysteroid dehydrogenase activity in rat follicular granulosa cells during proestrus. Bull. Acad. Pol. Sci. Cl. V Ser. Sci. Biol. 23, 65-69.

Piascek, B.E., Schneider, T.C. \& Gay, V.L. (1971) Sequential study of luteinizing hormone (LH) and "progestin" secretion on the afternoon of pro-estrus in rat. Endocrinology 89, 39-45.

Schwartz, N.B. (1969) A model for regulation of ovulation in the rat. Recent Prog. Horm. Res. 25, 1-55.

Shaikh, A.A. (1971) Estrone and estradiol levels in the ovarian venous blood from rats during estrous cycle and pregnancy. Biol. Reprod. 5, 297-307.

Smith, M.S., Freeman, M.E. \& Neill, J.D. (1975) The control of progesterone secretion during the estrous cycle and early pseudopregnancy in the rat; prolactin, gonadotropin and steroid levels associated with rescue of the corpus luteum of pseudopregnancy. Endocrinology 96, 219-226.

Szoltys, M. (1976) Progestagen dynamics in preovulatory follicles of rats. J. Reprod. Fert. 48, 397398.

YoungLai, E.V. \& Short, R.V. (1970) Pathways of steroid biosynthesis in the intact Graafian follicles of mares in oestrus. J. Endocr. 47, 321-333.

Received 19 January 1981 